\title{
OPTIMALISASI PERANCANGAN VIDEO PEMBELAJARAN BAHASA INGGRIS BERBASIS WEB
}

\author{
Herri Susanto \\ Rizki Pramudiningtyas \\ Muri Mukhrianto \\ Sekolah Tinggi Teknologi Bontang, Kalimantan Timur \\ Korespondensi: Jl. Ir. H. Juanda No 73 Bontang \\ Pos-el: herriaudrey@yahoo.com
}

\begin{abstract}
Abstrak
Tujuan umum penelitian ini adalah guna menunjang persiapan para siswa SMA/MAN/SMK dalam menghadapi Ujian Nasional dan Seleksi Bersama Masuk Perguruan Tinggi baik di Perguruan Tinggi Negeri maupun Perguruan Tinggi Swasta. Sedangkan tujuan khusus penelitian adalah; (1) mengoptimalisasi perancangan video pembelajaran bahasa Inggris melalui website, (2) menganalisa antusiasme siswa pengunjung website pembelajaran, dan (3) meningkatkan aktivitas edukasi siswa melalui internet. Kegiatan penelitian Optimalisasi perancangan ini memiliki tahap pelaksanaan berupa a) perancangan video pembelajaran bahasa Inggris, b) perancangan website, $c$ ) pengunggahan video pada website, d) sosialisasi website pada target penelitian yaitu siswa SMKN 3 kota Bontang, dan e) evaluasi keefektivan perancangan video berbasis website. Hasil penelitian ini memberikan gambaran bahwa fitur video pembelajaran sangat diminati oleh para siswa(89\%) dibandingkan fitur lainnya. Berikutnya hasil penelitian ini memberikan dampak antusiasme yang lebih menarik perhatian para siswa dan guru terhadap hadirnya web yang khusus menampilkan video pembelajaran bahasa Inggris beserta fitur pelengkap yang ada.
\end{abstract}

Kata-kata kunci: Pembelajaran bahasa Inggris, video pembelajaran,

optimalisasi website

\begin{abstract}
The purpose of the study generally is to facilitate high school students preparation for National Test and State/private Entrance Test and specifically the purposes are 1)to increase the activity of English learning videos through website, 2) to increase the learning activity through internet. The stages of this research consists of 5 stages such as; a) capturing English learning videos, b) creating website, c) uploading the videos to the website, $d)$ launching the website to the third year of Bontang State Vocational School 3, and e) evaluating the website content. The results show that video learning designs is the most chosen feature(89\%) than other features on the website. Furthermore, the questionaires reaveal that $100 \%$ give positive responses to the website given.
\end{abstract}

Keywords: Learning english, learning videos, websites Optimizing 


\section{PENDAHULUAN}

Perkembangan teknologi dan informasi meningkat pesat seiring dengan perubahan tingkah laku dan kebiasaan masyarakat modern (Anderson; 2012). kebiasaan masyarakt modern yang dimaksud adalah suatu rutinitas sehari-hari yang tidak pernah lepas dari kegiatan yang senantiasa bersinggungan dengan teknologi, misalnya televisi, handphone, laptop, internet, audio player dan sebagainya. Masyarakat tersebut secara rutin melakukannya dengan senang dan tanpa beban sehingga bisa saja akan mengarah pada satu tindakan yang disebut dengan technology addicted atau kecanduan teknologi. Oleh karena itu, teknologi bukanlah barang langka dalam kehidupan masyarakat sekarang. Dengan teknnologi masyarakat bisa melakukan aktifitas apapun bisa saja untuk berbelanja, bersosialisasi, bersenang-senang, bahkan untuk belajar dan mengajar.

Penelitian yang dilakukan oleh Malamuth dkk (2000: 84).menemukan bahwa kehadiran teknologi internet memberikan dampak negatif bagi anak-anak terutama terhadap kekerasan seksual,namun pada sisi lain juga banyak manfaat yang bisa diperoleh dari internet seperti .dalam penelitian yang berhubungan dengan pembelajaran, para siswa lebih senang belajar menggunakan visual seperti video yang ada didalam internet dibandingkan belajar konvensional atau tatap muka(contoh; Greenberg, 2012;Dodie, 2001; dan Osunade, 2003).

Menyikapi fenomena keberadaan teknologi dalam hal ini internet, peneliti sebagai pengajar bahasa Inggris dan dosen diprogram studi teknik informatika, ingin merancang sebuah website yang didalamnya terdapat video pembelajaran bahasa Inggris bagi siswa menengah baik SMA, MAN, maupun SMK. Berikutnya penelitian ini akan mengarahkan para siswa untuk mempelajari lebih jauh dengan memformat pembelajaran tersebut dalam bentuk video pembelajaran yang terunggah dalam sebuah website khusus. Seperti yang disampaikan pada website ThinkDigital.co.id bahwa pengunjung website youtube hingga saat ini bisa mencapai 3 milliar orang dalam sehari dan pengunjung terbanyak yaitu menonton tayangan hiburan seperti musik, olah raga dan lainnya.

Definisi media menurut Munadi (2008) berasal dari bahasa latin yaitu "medius" sebagai bentuk jamak dari kata "medium" yang bermakna perantara atau pengantar. Sedangkan media pembelajaran menurut Djamarah;2002 mendefinisikan media sebagai alat apa saja yang bisa digunakan sebagai penyalur pesan. Dari kedua definisi tersebut maka bisa ditarik kesimpulan bahwa media adalah suatu sarana penyampai pesan. Lebih jauh lagi, apabila dihubungkan dengan pembelajaran maka media pembelajaran adalah suatu sarana penyampai pesan pembelajaran. Oleh karena itu Association and Eduction for Communication Technogy (1997) juga menyatkan bahwa media pembelajaran merupakan sesuatu yang bisa menyalurkan pesan dan dapt merangsang pikiran, perasaan dan kemauan audien, sehingga mendorong terjadinya pembelajaran.

Oleh karena itu, dengan adanya pemanfaatan media pembelajaran maka akan semakin efektif hasil belajar para siswa. Menurut Azhar Arsyad (2003) mengemukakan bahwa terdapat 3 fungsi media ajar yaitu sebagai fungsi kognitif, afektif dan kompensatoris. Video merupakan salah satu media pembelajaran yang paling banyak diminati saat ini karena dengan menonton video maka baik audio, visual, fakta, prosedur dan prinsip konsep akan terpenuhi. Kembali, Azhar menjelaskan bahwa terdapat 6 sifat isi pelajaran atau materi yaitu fakta, pengenalan visual, prinsip konsep, prosedur, keterampilan dan yang keenam adalah sikap. Dari keenam sifat tersebut 4 sifat 
yaitu fakta, visual, konsep dan sikap sekaligus bisa diperoleh dengan cara pembelajaran menggunakan video.

Materi ujian masuk perguruan tinggi negeri sejak tahun 2008 sudah banyak mengalami perubahan. Perubahan yang dimaksud adalah perbedaan penekanan terhadap soal tata bahasa sudah mulai dihilangkan berubah menjadi wacana. Namun demikian, seperti yang nampak pada kumpulan soal materi ujian Mandiri perguruan tinggi penyelenggara seringkali masih menggunakan dua jenis soal yaitu tata bahasa dan wacana atau teks. Foster (2008) menyebutkan bahwa terdapat 16 materi ujian bahasa Inggris pada ujian SNMPTN UM Undip, UM-UGM maupun soal ujian perguruan swasta yang berhubungan dengan Grammar. Materi tersebut antara lain nampak pada tabel 2;

Tabel 2. Topik Soal Ujian SNMPTN,UM-UGM and UMB

(Foster, Bob. 2008:443)

\begin{tabular}{|l|l|l|l|}
\hline NO & \multicolumn{1}{|c|}{ TOPIK } & NO & \multicolumn{1}{c|}{ TOPIK } \\
\hline 1 & Passive voice & 9 & Tenses \\
\hline 2 & Conjunction & 10 & Conditional \\
\hline 3 & Modals & 11 & Subjunctive \\
\hline 4 & Elliptical Construction & 12 & Causative \\
\hline 5 & Derivatives & 13 & Infinitive \\
\hline 6 & Concord & 14 & Gerund \\
\hline 7 & Adjective clause & 15 & Direct-indirect Speech \\
\hline 8 & Words order & 16 & Dependent Clause \\
\hline
\end{tabular}

Maka secara umum, dari sekian banyak materi soal yang diujikan peneliti merasa bahwa penelitian ini penting untuk ditindak lanjuti yang difokuskan pada 12 pembahasan materi yang meliputi 2 jenis soal yaitu tata bahasa dan wacana. Berikut merupakan pembagian 2 jenis materi yang dijadikan topik bahasan materi bahasa Inggris.

\begin{tabular}{|c|c|}
\hline 1. Passive Voice & 6. Tenses \\
\hline 2. Modals & 7. Conditional Sentences \\
\hline 3. Concord & 8. Subjunctive Clause \\
\hline 4. Adjective Clause & 9. Gerund \\
\hline 5. Noun Clause & 10. Causative \\
\hline
\end{tabular}

Wacana yang diujikan untuk ujian masuk perguruan tinggi merujuk pada soal reading Toefl. Oleh karena itu, pembelajaran wacana akan diarahkan pada pembahasan wacana Toefl yaitu Blind Text atau cloze procedure, dan Topic and Main Idea

\section{METODE}

Penelitian ini menggunakan metode penelitian kualitatif yang didukung dengan penyebaran kuesioner dan obeservasi 
lapangan. Kuesioner disebarkan pada saat peneliti mengadakan uji lapangan dihadapan para guru dan siswa SMKN3 Bontang. Objek penelitian dalam pembuatan perancangan media pembelajaran video berbasis website ini adalah 56 siswa SMKN 3 kota Bontang, yang beralamat dijalan Imam Bonjol Kecamatan Bontang Selatan. Tahapan yang akan dilakukan dalam penelitian ini adalah: (1) Perumusan materi pembelajaran yang dibutuhkan. Pada langkah ini peneliti mencari referensi materi yang sering dimunculkan dalam ujian masuk perguruan tinggi, (2) Perancangan konsep perekaman aktifitas media pembelajaran berupa video. Peneliti akan membahas secara terperinci tahapan pengajaran yang terekam dalam bentuk video,

Perancangan website. Pada tahap ini membahas tentang konten, dan prosedur pengoperasian, (4) Mengintegrasikan video dengan website. Peneliti mulai mengunggah video yang telah dibuat kedalam website, (5) Sosialisasi website. Peneliti mengadakan workshop kepada siswa SMKN 3 Bontang, (6) Evaluasi perancangan yang merupakan tahap terakhir, peneliti mendistribusikan kuesioner kepada objek penelitian untuk memberikan tanggapan atas website yang telah dirancang.

\section{HASIL DAN PEMBAHASAN}

\section{Perancangan Website}

Sekaitan dengan perancangan website, menurut Jovan (2007) website adalah halaman informasi yang disediakan melalui jalur internet sehingga bias diakses diseluruh dunia selama website tersebut masih bias diakses dan terkoneksi dengan jaringan internet. Dalam menyajikan tampilannya, website memiliki komponen-komponen yang bias dikreasikan sesuai dengan keinginan pengguna misalnya menampilkan gambar, teks, suara, video, dan animasi.
Website sebagai sarana komunikasi dan media pembelajaran dalam penelitian ini website dinamis. Website dinamis bermakna bahwa website yang secara terstruktur diperuntukkan untuk bias dilakukan upaya update sesering mungkin. Sehingga pemilik website dapat melakukan perubahan guna perbaikan konten, tampilan maupun update program secara keseluruhan.Sebagai langkah selanjutnya dalam merancang website video pembelajaran, peneliti memerlukan bahasa pemrograman dan software dalam penyusunan Website.

\section{Hypertext Markup Language (HTML)}

Internet merupakan jaringan global yang menghubungkan suatu network dengan network lainya di seluruh dunia. Untuk membuat sebuah halaman di internet (homepage) bahasa yang digunakan adalah Hypertext Markup Language(HTML). LPKBM Madcoms (2007) menyatakan bahwa HTML merupakan standard bahasa yang di gunakan untuk menampilkan dokumen website, yang bisa dilakukan dengan HTML yaitu mengontrol tampilan dari web page dan isinya, mempublikasikan dokumen secara online sehingga bisa di akses dari seluruh dunia, membuat online form yang bisa digunakan untuk menangani pendaftaran, transaksi secara online, menambahkan objek-objek seperti image, audio, video dan juga java applet dalam dokumen $H T M L$.

HTML merupakan bahasa mark up (pengkodean) yang digunakan untuk menandai sebuah dokumen teks. Tanda tersebut digunakan untuk menentukan format atau style dari teks yang ditandai. Untuk menandai bahwa sebuah file teks merupakan file $H T M L$, maka ciri yang paling terlihat jelas adalah ekstensi filenya yaitu .htm atau .html. Struktur dasar html adalah sebagai berikut :

$<$ html> 
$<$ head $>$

$<$ title $>$ $</$ title $>$

$</$ head $>$

$<$ body $>$

$</$ body $>$

$</$ html $>$

Tag $\langle$ html $>$ tersebut harus diletakkan pada bagian awal dan tag $</$ html $>$ harus diletakkan pada bagian akhir dari suatu file HTML. Tag-tag HTML tidak bersifat case sensitive artinya huruf besar maupun kecil tidak menjadi masalah.

\section{Cascading Style Sheet(CSS)}

Cascading Style Sheet (CSS) menurut Untung Rahardja (2009) adalah suatu teknologi yang digunakan untuk memperindah halaman website. Dengan CSS dapat dengan mudah mengubah keseluruhan warna dan tampilan yang terdapat didalam situs. CSS merupakan fitur yang penting dalam membuat halaman HTML. Meskipun bukan merupakan suatu keharusan dalam membuat website, akan tetapi penggunaan CSS merupakan suatu kelebihan tersendiri. CSS mendeskripsikan bagaimana tampilan tampilan dokumen HTML di layar, dan sebagai tempat dimana programmer dapat mengontrol style yang ada. Secara teoritis programmer bisa CSS technology dengan HTML. Akan tetapi pada prakteknya hanya CSS technolgy yang harus support pada hampir semua web Browser. Karena CSS telah di standarkan oleh Word Wide Web Consortium (W3C) untuk digunakan di web browser.

\section{Hypertext Preposessor (PHP)}

PHP merupakan akronim dari singkatan rekursif PHP Hyertext Preposessor adalah bahasa pemrograman scripting yang dapat digunakan secara umum dan berbasis web. Selanjutnya M.Rudyanto Arief (2011) menjelaskan bahwa ada banyak bahasa pemrograman scripting yang dapat digunakan untuk membangun situs web, salah satunya yang paling banyak digunakan saat ini adalah PHP karena kesederhanaan sintaksnya dan kecepatan eksekusinya.

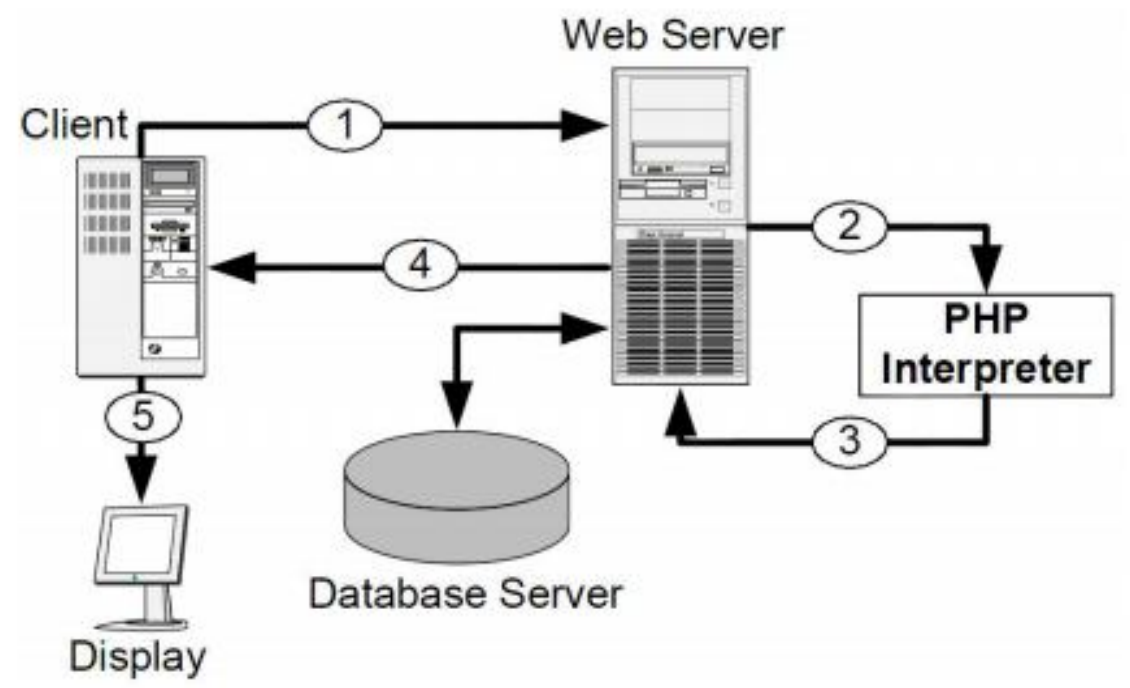

Menurut Ramadhan (2007) Macromedia Dreamweaver 8 Dreamweaver merupakan perangkat lunak yang ditujukan untuk membuat suatu situs 
web. Versi pertama dirilis pada tahun 1997 , dan sejak itu Dreamweaver menjadi web editor yang banyak digunakan oleh para web developer. Hal itu antara lain karena kemudahan dalam penggunaannya, kelengkapan fiturnya dan juga dukungannya terhadap teknologi terkini. Dreamweaver 8 merupakan salah satu perangkat lunak yang dikembangkan oleh Macromedia Inc. Pada Dreamweaver 8, terdapat beberapa kemampuan bukan hanya sebagai software untuk mendesain web saja tetapi juga untuk menyunting kode serta pembuatan aplikasi Web dengan menggunakan berbagai bahasa pemrograman Web, antara lain: JSP, PHP, ASP dan ColdFusion.

\section{Rancangan User Interface}

Berikut ini merupakan gambar tampilan tampilan website yang terdiri atas 12 fokus konten. Berikut penjelasan 12 konten tersebut:

a. Header, merupakan bagian awal dalam sebuah website, dimana pengunjung dapat mengetahui website apa yang meraka kunjungi.

b. Home, merupakan menu utama bagi pengguna untuk kembali ke halaman utama (homepage) ketika sedang menjelajahi halaman website.

c. Galery, sebagai media penyimpanan file dalam website.

d. Artikel, berisi kumpulan artikel pembelajaran bahasa Inggris.

e. Buku tamu, berfungsi sebagai media dimana pengunjung dapat mengisi buku tamu untuk memberikan komentar dari isi keseluruhan website.

f. Daftar video, berisi daftar video dimana akan memudahkan pengunjung untuk mencari video.

g. Jumlah pengunjung, untuk mengetahui berapa banyak pengunjung yang telah mengunjngi halaman website tersebut.

h. Indeks, berisi berita terbaru dalam halaman utama website

i. Bahan materi, berisi materi pendukung.

j. Footer, berfungsi untuk menampilkan informasi website tersebut, seperti Copyright, Powered by atau nama dari website.

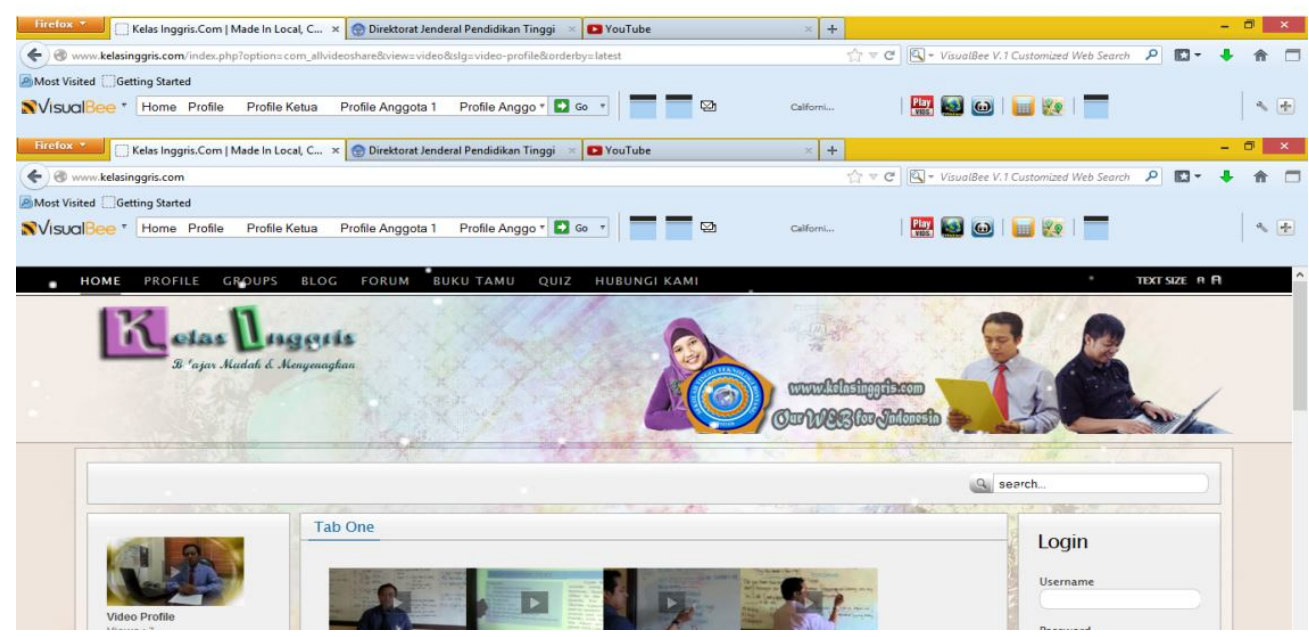

Gambar 1. Tampilan Website

\section{Perumusan materi pembelajaran}


Materi yang diujikan dalam dalam Ujian Nasional maupun Seleksi Bersama Masuk Perguruan Tinggi sebagian besar terdiri atas materi wacana dan tata bahasa. Foster (2008) menjabarkan bahwa terdapat 16 materi ajar yang sering muncul dalam ujian masuk perguruan tinggi.

\section{Perancangan Video}

Tabel 2. Materi Video Pembelajaran Bahasa Inggris

\begin{tabular}{|c|l|}
\hline NO & TOPIK VIDEO PEMBELAJARAN \\
\hline 1 & Cloze Text \\
\hline 2 & Descriptive Text \\
\hline 3 & Gerund \\
\hline 4 & Agreement /Concord \\
\hline 5 & Passive voice \\
\hline 6 & Adjective clause/Relative Pronoun \\
\hline 7 & Causative \\
\hline 8 & Conditional Sentences \\
\hline 9 & Noun Clause \\
\hline
\end{tabular}

\section{Perancangan Website}

Pada tahap ini website yang telah dirancang www.kelasInggris.com. Konten website
Ketua peneliti adalah dosen bahasa Inggris oleh karena itu sebagai prototype pengajaran maka peneliti akan bertindak sebagai pengajar yang membahas secara terperinci tahapan pengajaran yang terekam dalam bentuk video. Video pembelajaran yang telah terekam sebanyak 9 video dengan topik sebagai berikut:

telah dilengkapi dengan fitur-fitur, menu, tata letak video, artikel dan prosedur pengoperasian lainya. Berikut gambar fiturfitur website www.kelasInggris.com:

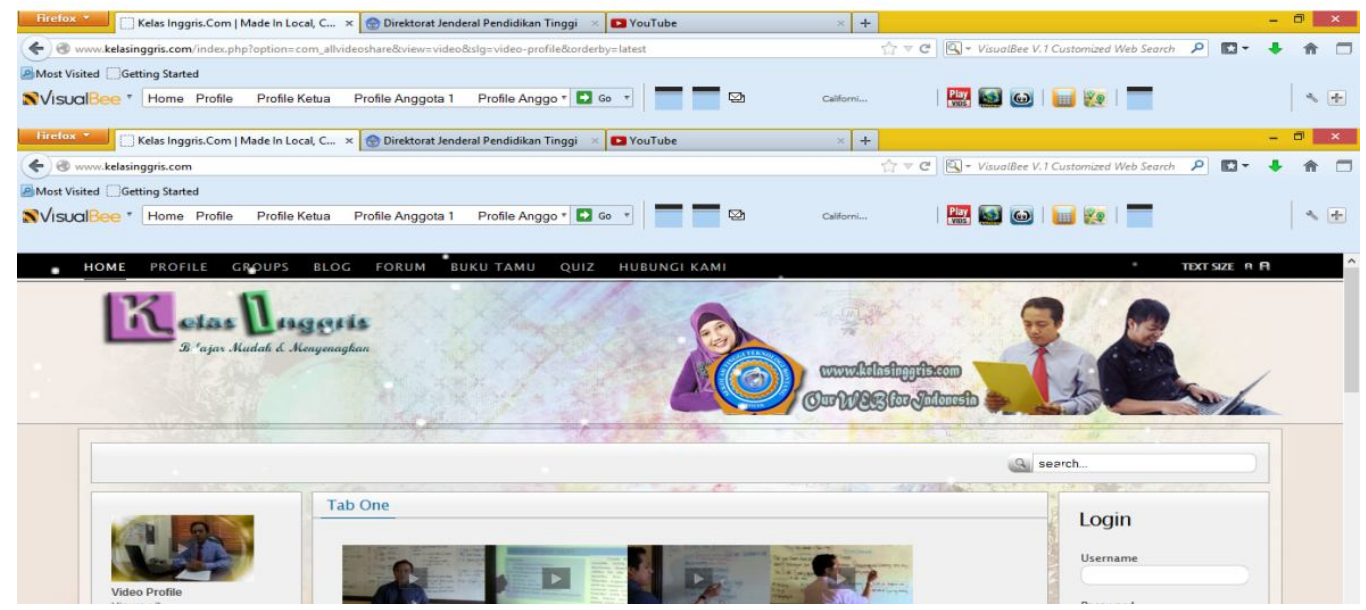

Gambar 2. Website: www.kelasInggris.com

\section{Integrasi Video dengan Website}


Peneliti mengunggah 9 video yang telah dibuat kedalam website.

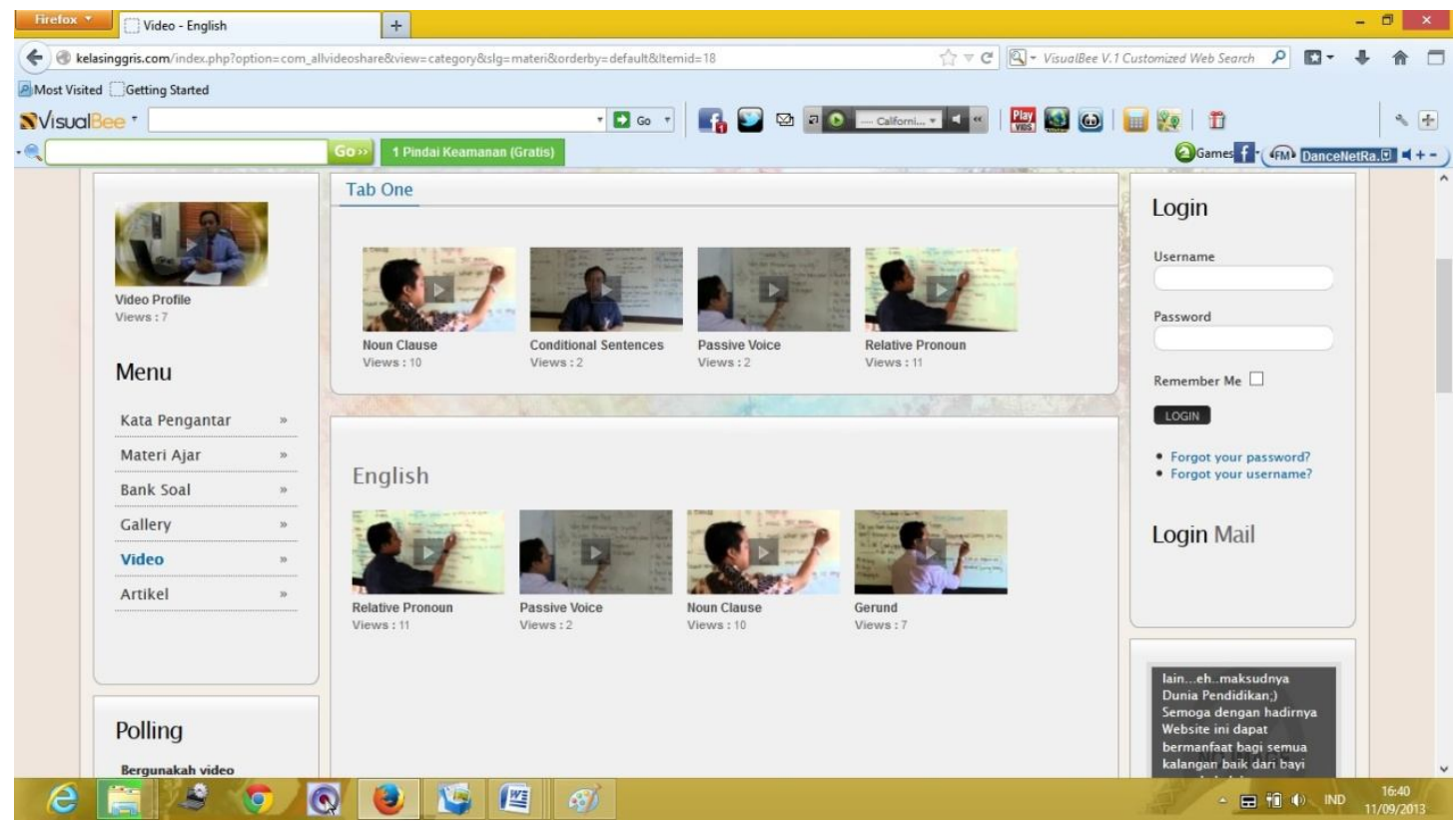

Gambar 3. Galery Video Pembelajaran

Video tersebut selanjutnya juga telah terintegrasi dengan www.youtube.com. Apabila pengunjung mengingikan satu video pembelajaran bahasa Inggris yaitu topik passive voice, maka pengunjung bisa mengetik kata kunci pada log pencarian di situs youtube yaitu dengan kata kelas Inggris passive voice maka secara otomatis akan terdeteksi video pembelajaran yang dimaksud dengan alamat yang sama yaitu www.kelasInggris.com.

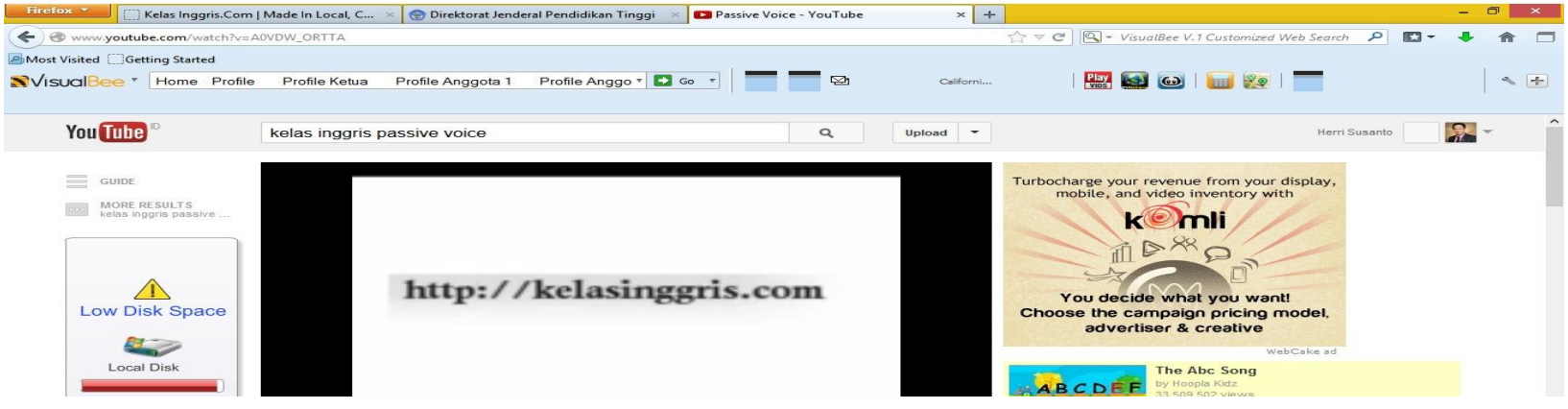

Gambar 4. Kelas Inggris di www.youtube.com 


\section{Uji Lapangan}

Uji lapangan dilakukan melalui tiga bentuk pengamatan hasil yaitu: (1) Peneliti meminta saran dan pendapat ahli TI yang ada dilingkungan kampus STITEK Bontang. Hasil pengujian website menyimpulkan bahwa website yang dirancang dapat berjalan dengan lancar dan valid, (2) Peneliti kemudian mengadakan sosialisasi kepada para guru dan siswa SMKN 3 Kota Bontang pada tanggal 19 September 2013. Pada tahap ini peneliti menyebarkan kuesioner kepada objek penelitian untuk memberikan tanggapan atas website yang telah dirancang. Kuesioner tersebut diperuntukkan bagi siswa SMKN 3 Bontang. Masing-masing kuesioner terdiri atas 10 pertanyaan dengan 4 alternatif jawaban serta 1 kolom komentar dari setiap siswa yang memberikan komentar.

\begin{tabular}{|c|c|}
\hline No & $\begin{array}{c}\text { Pertanyaan Uji Lapangan Website } \\
\text { www.kelasInggris.com }\end{array}$ \\
\hline 1 & Seberapa sering Anda berinteraksi dengan internet? \\
\hline 2 & $\begin{array}{l}\text { Dalam } 1 \text { hari, biasanya berapa lama waktu yang Anda butuhkan untuk berinteraksi } \\
\text { dengan internet? }\end{array}$ \\
\hline 3 & Aktifitas apa saja yang anda lakukan pada saat Anda lakukan saat online/internet? \\
\hline 4 & $\begin{array}{l}\text { Manakah konten yang paling Anda sukai sebagai rutinitas memanfaatkan internet dalam } \\
\text { kegiatan sehari-hari? }\end{array}$ \\
\hline 5 & $\begin{array}{l}\text { Seberapa sering Anda menonton video pembelajaran atau pendidikan di internet?misal } \\
\text { situs YouTube? }\end{array}$ \\
\hline 6 & $\begin{array}{l}\text { Apakah Anda tertarik terdapat konten video-web peneliti yang berisi materi UN dan } \\
\text { Seleksi Bersama Masuk Perguruan Tinggi ini? }\end{array}$ \\
\hline 7 & nggunakan video web ini penting untuk dikembangkan? \\
\hline 8 & nonton video web ini dimasa yang akan datang? \\
\hline 9 & nati dalam web ini? \\
\hline 10 & eluruhan apa pendapat Anda dengan penyeler \\
\hline
\end{tabular}

Peneliti selanjutnya mengadakan observasi atas website www.kelasInggris.com yang telah dirancang dengan mengamati jumlah pengunjung, komentar pesan dan voting kegunaan website bagi pengunjung. Hasil rekapitulasi kuesioner siswa yang diperoleh dari uji lapangan adalah sebagai berikut. 


\section{Rekapitulasi Kuesioner Siswa \\ Terhadap Rancangan Website www.kelasInggris.com}

\begin{tabular}{|c|c|c|c|c|c|c|c|c|c|}
\hline \multirow{3}{*}{$\begin{array}{c}\text { No } \\
1 \\
1\end{array}$} & \multirow{3}{*}{$\begin{array}{c}\sum \text { Siswa } \\
56\end{array}$} & \multicolumn{8}{|c|}{ Pilihan } \\
\hline & & \multicolumn{2}{|r|}{$\mathbf{a}$} & \multicolumn{2}{|c|}{ b } & \multicolumn{2}{|c|}{ c } & \multicolumn{2}{|c|}{ d } \\
\hline & & 45 & 80 & 10 & 18 & 1 & 2 & 0 & - \\
\hline 2 & 56 & 5 & 9 & 38 & 68 & 8 & 14 & 5 & 9 \\
\hline 3 & 56 & 50 & 89 & 18 & 32 & 0 & - & 36 & 64 \\
\hline 4 & 56 & 31 & 55 & 16 & 29 & 2 & 4 & 50 & 89 \\
\hline 5 & 56 & 0 & - & 2 & 4 & 6 & 11 & $\overline{48}$ & 86 \\
\hline 6 & 56 & 47 & 84 & 9 & 16 & 0 & - & 0 & - \\
\hline 7 & 56 & 48 & 86 & 8 & 14 & 0 & - & 0 & - \\
\hline 8 & 56 & 40 & 71 & 16 & 29 & 0 & - & 0 & - \\
\hline 9 & 56 & 50 & 89 & 0 & - & 0 & - & 6 & 11 \\
\hline 10 & 56 & 37 & 66 & 19 & 34 & 0 & - & 0 & - \\
\hline
\end{tabular}

1. Seberapa sering Anda berinteraksi dengan internet?

\begin{tabular}{|l|c|l|l|}
\hline a)Sering & $\begin{array}{l}\text { b) Kadang- } \\
\text { kadang }\end{array}$ & $\begin{array}{l}\text { c) } \\
\text { jarang }\end{array}$ & $\begin{array}{l}\text { d) tidak } \\
\text { pernah }\end{array}$ \\
\hline 45 siswa & 10 siswa & 1 siswa & 0 siswa \\
\hline
\end{tabular}

Pada pertanyaan ini siswa telah menjawab ketiga pilihan yaitu poin a sampai dengan c namun tidak memilih d. Kesimpulannya adalah sebanyak $80 \%$ siswa sering berinteraksi dengan internet. Oleh karena itu dapat dikatakan bahwa keseharian para siswa selalu bersentuhan dengan dunia maya.

2. Dalam 1 hari, biasanya berapa lama waktu yang Anda butuhkan untuk berinteraksi dengan internet?

\begin{tabular}{|c|l|l|l|}
\hline a) >3 jam & $\begin{array}{l}\text { b) 1-3 } \\
\text { jam }\end{array}$ & c) 1 jam & $\begin{array}{l}\text { d) }<1 \\
\text { jam }\end{array}$ \\
\hline 5 siswa & $\begin{array}{c}38 \\
\text { siswa }\end{array}$ & 8 siswa & 5 siswa \\
\hline
\end{tabular}

Jika 1 sampai dengan 3 jam merupakan pilihan terbanyak siswa dalam menggunakan internetyaitu 38 siswa dan 5 orang yang menggunakannya lebih dari 5 jam serta sisanya masih juga menggunakan internet meskipun kurang dari 1 jam berarti kondisi ini adalah hal yang luar biasa seperti yang disebutkan pada kuesioner kedua bahwa $80 \quad \%$ mereka bersentuhan dengan internet.

3. Aktifitas apa saja yang anda lakukan pada saat Anda lakukan saat online/internet? 


\begin{tabular}{|l|l|l|l|}
\hline $\begin{array}{l}\text { a)browsi } \\
\text { ng }\end{array}$ & $\begin{array}{l}\text { b) } \\
\text { download } \\
\text { ing }\end{array}$ & $\begin{array}{l}\text { c) } \\
\text { uploadi } \\
\text { ng }\end{array}$ & $\begin{array}{l}\text { d) } \\
\text { comment } \\
\text { ing }\end{array}$ \\
\hline 50 siswa & 18 siswa & 0 siswa & 36 siswa \\
\hline
\end{tabular}

Aktifitas terbanyak adalah browsing dan melakukan komentar di media sosial seperti facebook, whatsup, dan lainnya.

4. Manakah konten yang paling Anda sukai sebagai rutinitas memanfaatkan internet dalam kegiatan sehari-hari?

\begin{tabular}{|l|l|l|l|}
\hline $\begin{array}{l}\text { a) } \\
\begin{array}{l}\text { Meno } \\
\text { nton } \\
\text { Video }\end{array}\end{array}$ & $\begin{array}{l}\text { b) } \\
\text { arkandeng } \\
\text { Musik }\end{array}$ & $\begin{array}{l}\text { c) memb } \\
\text { aca } \\
\text { artike } \\
1\end{array}$ & $\begin{array}{l}\text { d) membuka } \\
\text { situs media } \\
\text { social } \\
\text { (facebook/tw } \\
\text { itterdll) }\end{array}$ \\
\hline $\begin{array}{c}31 \\
\text { siswa }\end{array}$ & 16 siswa & $\begin{array}{c}2 \\
\text { siswa }\end{array}$ & 50 siswa \\
\hline
\end{tabular}

Media sosial merupakan media yang sangat disukai oleh para siswa serta menonton video adalah pilihan kedua para siswa. Berdasarkan hasil pengamatan didapatkan bahwa ratarata video yang ditonton adalah berasal dari situs youtube.

5. Seberapa sering Anda menonton video pembelajaran atau pendidikan di internet?misal situs YouTube?

\begin{tabular}{|c|l|l|c|}
\hline a)Sering & $\begin{array}{l}\text { b) } \\
\text { Kadang- } \\
\text { kadang }\end{array}$ & $\begin{array}{l}\text { c) } \\
\text { jarang }\end{array}$ & $\begin{array}{l}\text { d) tidak } \\
\text { pernah }\end{array}$ \\
\hline 0 siswa & 2 siswa & 6 siswa & $\begin{array}{c}48 \\
\text { siswa }\end{array}$ \\
\hline
\end{tabular}

Fakta berikut yang menyatakan bahwa $86 \%$ siswa tidak pernah membuka video pembelajaran di website. Informasi ini bisa saja merupakan penanda bahwa ditempat lain selain kota Bontang para pengguna website terutama siswa atau remaja memiliki kecenderungan selalu berinteraksi didunia maya dan mengunjungi website youtube.

6. Apakah Anda tertarik terdapat konten video-web peneliti yang berisi materi UN dan Seleksi Bersama Masuk Perguruan Tinggi ini?

\begin{tabular}{|l|l|l|l|}
\hline $\begin{array}{l}\text { a) Sangat } \\
\text { tertarik }\end{array}$ & $\begin{array}{l}\text { b) } \\
\text { Biasa } \\
\text { saja }\end{array}$ & $\begin{array}{l}\text { c) kurang } \\
\text { tertarik }\end{array}$ & $\begin{array}{l}\text { d) tidak } \\
\text { tertarik }\end{array}$ \\
\hline 47 siswa & 9 siswa & 0 siswa & 0 siswa \\
\hline
\end{tabular}

Pada saat uji lapangan para siswa antusias mengikuti kegiatan tersebut dan respon yang dilakukan adalah 47 siswa atau $84 \%$ tertarik dengan konten website kelasInggris.com.

7. Menurut Anda pembelajaran menggunakan video web ini penting untuk dikembangkan?

\begin{tabular}{|l|l|l|l|}
\hline $\begin{array}{l}\text { a) } \\
\text { Sangat } \\
\text { penting }\end{array}$ & $\begin{array}{l}\text { b) } \\
\text { Penting }\end{array}$ & $\begin{array}{l}\text { c) tidak } \\
\text { terlalu } \\
\text { penting }\end{array}$ & $\begin{array}{l}\text { d) tidak } \\
\text { penting }\end{array}$ \\
\hline 48 siswa & 8 siswa & 0 siswa & 0 siswa \\
\hline
\end{tabular}

Empat puluh delapan respon menyatakan bahwa video web ini sangat penting untuk dikembangkan.

8. Apakah Anda berminat untuk menonton video web ini dimasa yang akan datang?

\begin{tabular}{|l|l|l|l|}
\hline $\begin{array}{l}\text { a) } \begin{array}{l}\text { Sangat } \\
\text { berminat }\end{array} \\
\text { 40 siswa }\end{array}$ & Berminat & $\begin{array}{l}\text { c) siswa } \\
\text { kurang } \\
\text { berminat }\end{array}$ & $\begin{array}{l}\text { d) } \\
\text { kurang } \\
\text { berminat }\end{array}$ \\
\hline \multicolumn{3}{|c|}{ Pada saat uji lapangan siswa } \\
diperkenalkan dan siswa mencoba \\
sendiri website
\end{tabular}
www.kelasInggris.com, respon para siswa menunjukkan bahwa mereka memiliki minat yang besar untuk melanjutkan memanfaatkan video web tersebut. $100 \%$ siswa menyatakan berminat dan sangat 
berminat untuk menonton video web tersebut dimasa yang akan datang.

9. Konten apa yang paling Anda minati dalam web ini?

\begin{tabular}{|c|l|l|l|}
\hline $\begin{array}{c}\text { a.Video } \\
\text { pembela } \\
\text { jaran }\end{array}$ & $\begin{array}{l}\text { b) } \\
\text { Penjelasa } \\
\mathrm{n} \mathrm{materi} \\
\text { (Pdf) }\end{array}$ & $\begin{array}{l}\text { c) } \\
\text { Soal } \\
\text { latiha } \\
\mathrm{n}\end{array}$ & $\begin{array}{l}\text { d) } \\
\text { semuany } \\
\mathrm{a}\end{array}$ \\
\hline 50 siswa & 0 siswa & $\begin{array}{c}0 \\
\text { siswa }\end{array}$ & 6 siswa \\
\hline
\end{tabular}

Terdapat 6 siswa yang memilih bahwa mereka menyukai semua konten yang disajikan dan 50 siswa yang menyukai konten video pembelajaran. Secara keseluruhan apa pendapat Anda dengan penyelenggaraan acara sosialisasi ini?

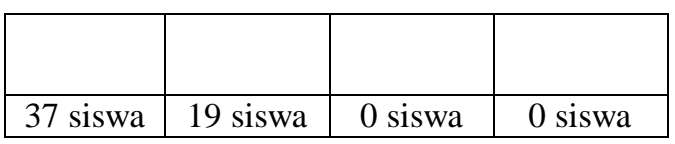

Acara sosialisasi dan uji lapangan mendapat sambutan yang sangat baik bagi para siswa dan guru di SMKN 3 Bontang sehingga nampak pada hasil kuesioner yang menyatakan bahwa 19 siswa menyatakan bagus dan 37 siswa yang menyatakan bagus sekali.

\section{Jumlah Pengunjung}

Dalam kurun waktu sejak tanggal 19 Sepetmber sampai dengan tanggal 1 November adalah sebanyak 27.764 pengunjung.

\begin{tabular}{|l|l|l|l|}
\hline $\begin{array}{l}\text { a) bagus } \\
\text { sekali }\end{array}$ & b) Bagus & c) cukup & $\begin{array}{l}\text { d) kurang } \\
\text { sekali }\end{array}$ \\
\hline
\end{tabular}

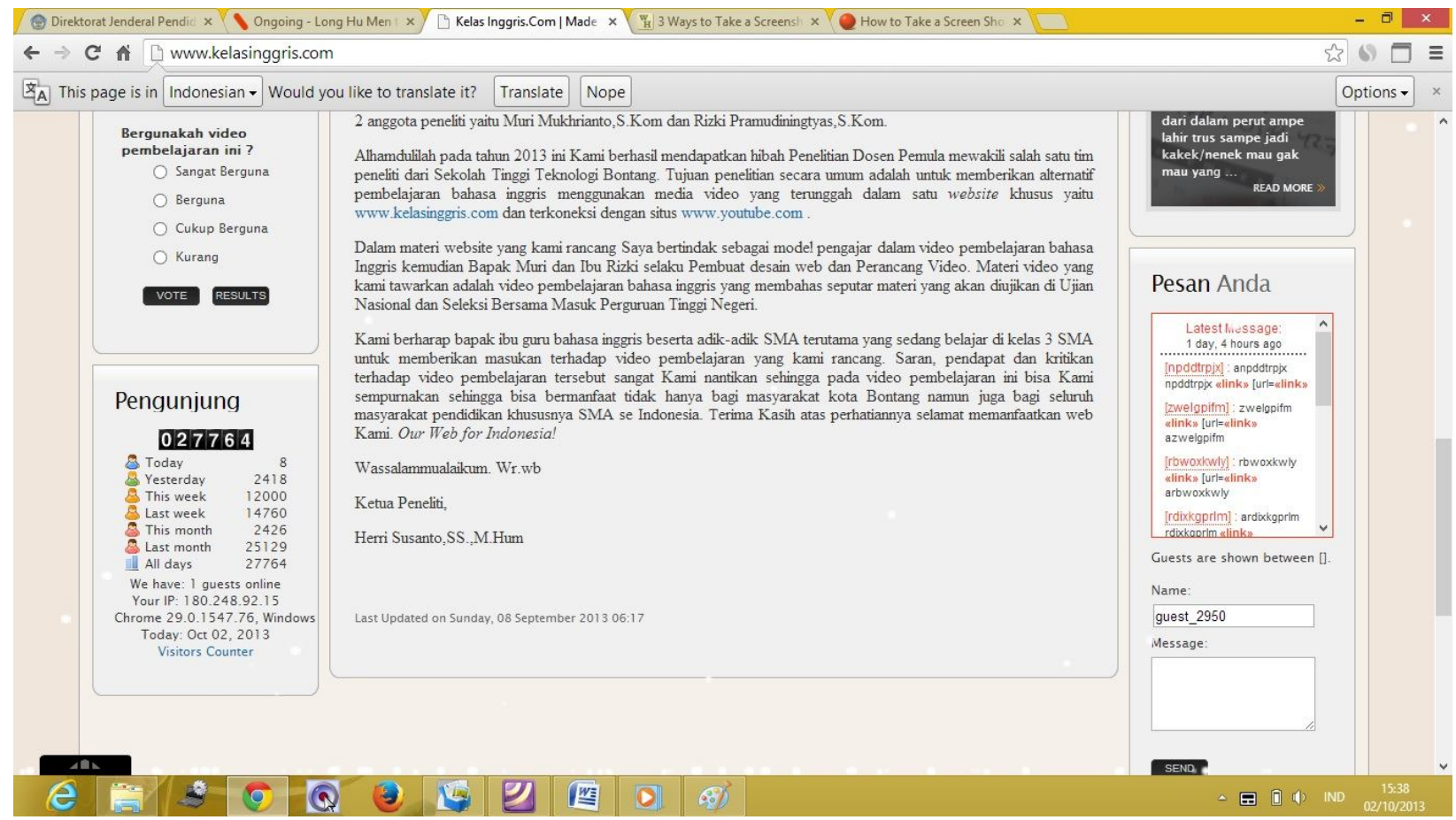

Begitu pula dengan voting yang dilakukan oleh pengguna website yaitu menyatakan
69,6 menyatakan video pembelajarannya sangat berguna dan 30,4 menyatakan bahwa video pembelajarannya berguna. 


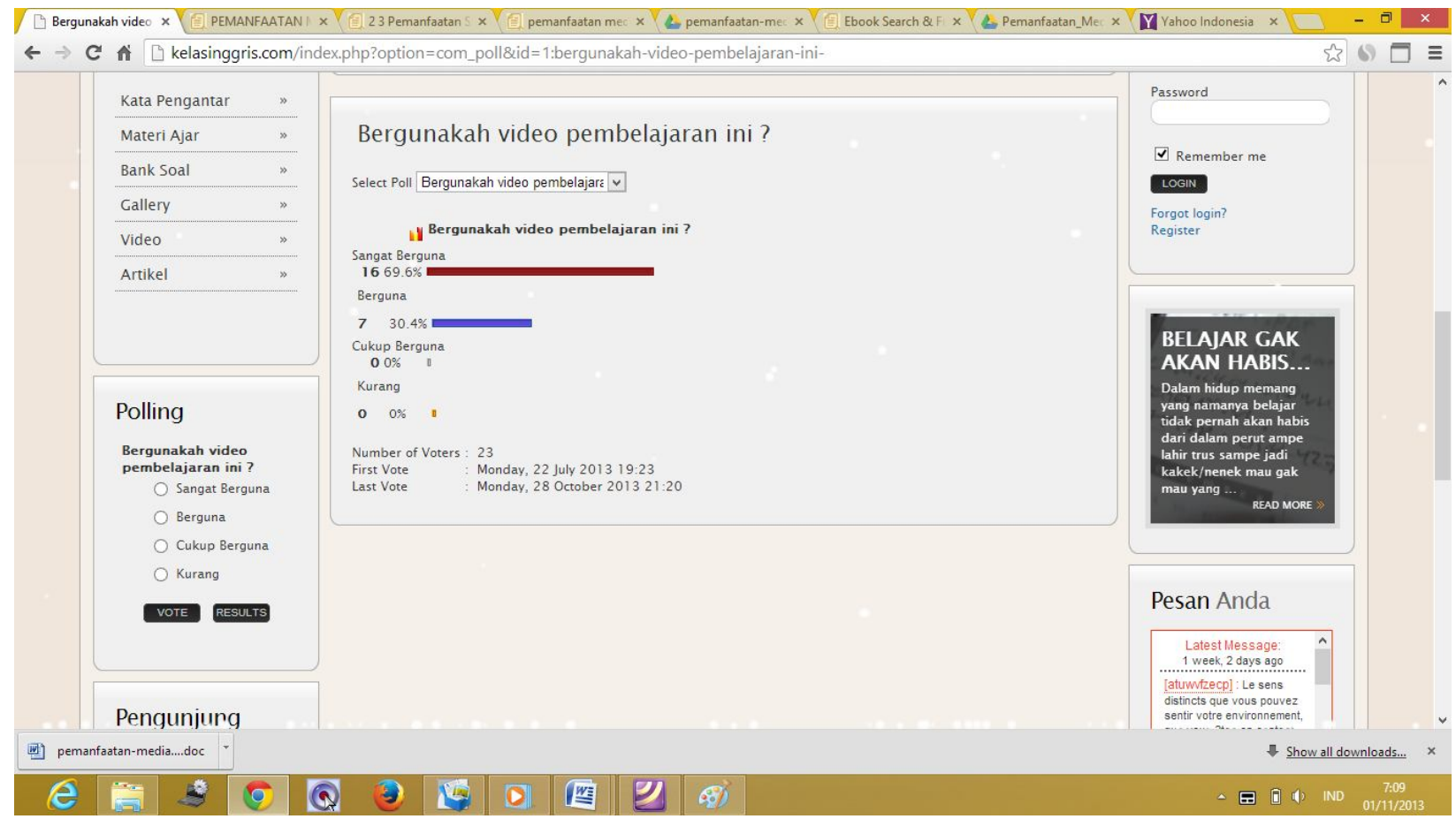

\section{SIMPULAN DAN SARAN}

Berdasarkan hasil penelitian Optimalisasi Pemanfaatan Perancangan Video Pembelajaran Bahasa Inggris Berbasis Web ini maka peneliti menyimpulkan bahwa: (1) Sebagian besar responden menyatakan bahwa website pembelajaran bahsa Inggris berbasis web ini sudah sangat baik, (2) Penilaian siswa terhadap konten, tampilan maupun kegunaan website menunjukkan respon yang positif sehingga akan mendorong siswa yang lain dalam mempelajari website tersebut, (3) Video pembelajaran yang ada masih belum sempurna baik dari sisi gambar video yang ditampilkan maupun suara yang muncul saat pembelajaran dimulai, (4) Website kelasInggris berpotensi untuk terus dikembangkan guna menjawab kebutuhan siswadan pendidik terhadap bentuk pembelajaran non-konvensional.

Peneliti menyarankan agar dilakukan tindak lanjut penelitian ini berupa: (1) Perbaikan konten website perlu dilengkapi dan disempurnakan terutama pada dua hal yaitu kualitas gambar dan suara pada video pembelajaran, (2) Penambahan jumlah video pembelajaran perlu terus ditambahkan dan dikembangkan keranah diluar materi UN dan SBMPT yaitu materi pembahasan TOEFL dan TOEIC.

\section{UCAPAN TERIMA KASIH}

Peneliti memberikan penghargaan yang setinggi-tingginya terhadap segenap pihak-pihak yang telah membantu terlaksananya penelitian Perancangan Video Pembelajaran Bahasa Inggris Berbasis Web. Pihak-pihak tersebut diantaranya adalah Dikti selaku penyandang dana penelitian dosen pemula, para staff dosen STITEK Bontang atas dukungannya, para guru dan siswa SMKN 3 Bontang ats partisipasinya memberikan saran dan masukan serta membantu pengisian kuesioner, serta tim peneliti yang sangat berkomitmen menyelesaikan proses penelitian ini setahapdemi setahap. 


\section{PUSTAKA RUJUKAN}

AECT.(1997). Definisi Teknologi Pendidikan: Satuan Tugas Definisi dan Terminology AECT, (terj.), Jakarta: Pusat Antar Universitas Terbuka \& RajaGrafindo Persada.

Anderson, J. Q. (2012). The Future Impact of the Internet on Higher Education. Elon University. Pew Research Center. Diakses tanggal 10 Maret di www. pewInternet.org.

Arsyad, A.(2003). Media Pembelajaran, Jakarta: RajaGrafindo Persada.

Dodie, I. M. (2003). The Impact of New Technologies and The Internet on The Music Industry, 1997-2001. Thesis. (University of Salfold, UK).

Djamrah, S.B.(2002). Strategi Belajar Mengajar. Jakarta. Rineka Cipta.

Foster, B \& Mulyana, A. (2008). Kumpulan Soal dan Pembahasan Bahasa Inggris SNMPTN 2001 - 2008, UMUGM 2003-2008, dan UMB 2008 Soal dan Pembahasan. Bandung: Ganesha Operation.

Greenberg, D. A., \& Zanetis, J.(2012). The Impact of Broadcast and Streeming Video and Education. Cissco. Wein Reserach.
LPKBM Madcoms.(2007). Seri Panduan Lengkap Macromedia Dreamweaver 8, Madiun: Penerbit Andi.

Malamuth, M., Neil, T.A., \& Koss, M. (...) Pornography and Sexual Agression: Are There ReliableEffects and Can we Understand Them? Annual Review of Sex Research. Vol: 11. Pp. 26-91.

Munadi, Y.(2008). Media Pembelajaran, Sebuah Pendekatan Baru, Gaung Persada Press, Ciputat.

Ramadhan, A.(2011). Pemrograman Web Dinamis menggunakan PHP dan MySQL, Madiun : Penerbit Andi.

Ramadhan, A.(2007). Macromedia Dreamweaver 8, Jakarta : Elex Media.

Osunade, O. (2003). An Evaluation of The Impact of The Internet Browsing on Students' Academic Performance at TertiaryLevel of Education in Negeria. Laporan Penelitian. ERNWACA. Nigeria. Diakses pada tanggal 11 Maret $2013 \quad$ di www.rocare.org/smallgrant_nigeria20 03.pdf

Rahardja, U. (2009). Siapa saja bisa membuat website dengan CSS dan HTML, Madiun : Penerbit Andi.

http://www.thinkdigital.co.id/youtube-thepart-of-viral-marketing/diakses Rabu 12 Maret 2013. 